\title{
URBAN NATURE BETWEEN MODERN AND POSTMODERN AESTHETICS: REFLECTIONS BASED ON THE SOCIAL CONSTRUCTIVIST APPROACH
}

\author{
OlaF KÜHNE \\ Endowed Chair of Sustainable Development, Saarland University, Saarbrücken, Germany \\ Manuscript received: June 30, 2011 \\ Revised version: February 27, 2012
}

\begin{abstract}
KÜHNE O., Urban nature between modern and postmodern aesthetics: Reflections based on the social constructivist approach. Quaestiones Geographicae 31(2), Bogucki Wydawnictwo Naukowe, Poznań 2012, pp. 61-70. 1 table, 2 figs. DOI 10.2478/v10117-012-0019-3, ISSN 0137-477X.

AвSTRACT. The article deals with the question of the social construction and assessment of physical urban objects (such as trees, gardens, parks) which are perceived as natural. The society perceives nature ambivalently. Nature describes "the primary and the good (...) that contrasts with society as the artificial and even the destructive". Nevertheless nature means "the wild and the threatening which is domesticated to protect society" (Groß 2006: 5). In the city, nature exists in a domesticated form (e.g. as a park) or in a less domesticated condition (e.g. as sparse flora). Modernity and postmodernity have different implications in the perception and assessment of urban nature. Especially the less domesticated nature contradicts the modern aesthetic scheme. It is assumed that the antagonism of legitimated and trivial culture is a substantial characteristic of modernity, which incorporates itself in a series of fundamental dichotomies like nature and culture (Fuller 1992). A typical characteristic of the modern dichotomy is the construction of order and disorder. By contrast, postmodern aesthetics challenges and deconstructs these dichotomies (Sloterdijk 1987, 1988). Unlike modernity, postmodernity tolerates the less domesticated nature in cities which includes new possibilities of the composition of the cityscape, especially for ruined buildings and areas. Postmodern landscape planning and architecture do not mean 'anything goes', but rather including the pluralism of citizens' interests, belongings and needs, especially because they are the sovereigns in democratic societies. In consequence, the postmodern perspective on planning can be an integral part of the sustainable development of cities.
\end{abstract}

KEY wORDS: sustainability, constructivism, nature, city, aesthetics, postmodernism

Olaf Kühne, Saarland University Endowed Chair of Sustainable Development, Preußenstraße 58, 66123 Saarbrücken, Germany; email: o.kuehne@mx.uni-saarland.de

\section{Introduction}

This article deals with the social construction and assessment of urban physical objects which are perceived as natural, such as plants. From the social constructivism point of view, there is "nowhere such a thing as a pure and simple fact" (Schütz 1971: 5). The previous knowledge of the world shapes every perception. Hence, our way of seeing the world is the result of a "highly complex interpretation process" (Schütz 1971: 123-124) rather than an isolated event. Within this process, "current perceptions and earlier perceptions" (Schütz 1971: 123-124) are juxtaposed (Hartz \& Kühne 2010).This article makes social constructivism in the tradition of Schütz's (1972) and Croce's (1995) philosophical approaches (see Kühne 2008) accessible to the planning process 
and design practice. Additionally, some empirical findings will be presented. The data come from studies on the social construction of landscape (Kühne 2006) and on participative processes in the practice of landscape planning (Hartz \& Kühne 2007, 2009, 2010).

\section{The social construction of landscape, nature and culture}

The constructivist paradigm is based on the concept that human consciousness could construct its environment but could not understand it without preconceptions (Foerster 1992). This epistemological position stems from the neurological research of Maturana \& Varela (1987): the nervous system is related to itself and closed, without direct access to its environment. In consequence, human consciousness can be described as autopoietic in the sense of self-constituting. People learn the specific patterns of interpretation and assessment through social interaction, which is an important part of life experience (Solso, MacLin \& MacLin 2008). With this as a background, landscape cannot be understood as a given object, but rather as a socially defined construct of human consciousness. In the process of socialisation human beings learn to apprehend what may be designated as landscape. Moreover, they learn the connections in which these designs apply without losing social acceptation when misdone. Determining cities as landscapes might involve the deprivation of social acceptation. The universal socially accepted definition of landscapes, particularly a beauty landscape, is historically evolved (Kühne 2008, Hartz \& Kühne 2009). Landscape is considered a social and individual 'construction' based on a selection of objects that embeds social meanings in a physical space. From the perspective of cognition psychology, human consciousness observes the environment by using senses and finds then fitting patterns of landscape that declares the observed objects to be a landscape. The patterns of landscape are learned in the process of socialisation, in school, from parents, in peer groups, from colleagues, and so on (Kühne 2008). The processes of perception and interpretation create what we call landscape as a new overall relationship. Simmel (1990: 71) compares the construction of a landscape to the production of a piece of art. The representation of a landscape is derived from the variety and endlessness of the objects of the given world. An individual construction of a landscape in this process is based on societal conditioning. However, different human beings may have different patterns: the distinctly individual knowledge about landscapes is caused by differences in the socialisation in different cultures, in different social milieus, in different schools and by different previous experiences of landscape. Especially natural objects are part of the social and individual construction of landscape (Table 1).

Table 1. 'What belongs to a landscape?' Survey in the Saarland: 455 survey participants, several answers possible.

\begin{tabular}{|c|c|c|c|c|c|}
\hline & $\begin{array}{c}\text { Percent- } \\
\text { age }\end{array}$ & Mentions & & $\begin{array}{l}\text { Percent- } \\
\text { age }\end{array}$ & Mentions \\
\hline Woods & 96.26 & 438 & Smaller towns & 32.09 & 146 \\
\hline Meadows & 95.16 & 433 & Single people & 21.32 & 97 \\
\hline Brooks & 91.21 & 415 & Sounds & 20.88 & 95 \\
\hline Villages & 83.08 & 378 & Groups of people & 19.56 & 89 \\
\hline Farms & 73.63 & 335 & Industrial firms & 14.07 & 64 \\
\hline Scents & 61.54 & 280 & Wind generators & 10.99 & 50 \\
\hline $\begin{array}{l}\text { Atmospheres (in the sense of } \\
\text { moods) }\end{array}$ & 60.66 & 276 & Cities & 8.79 & 40 \\
\hline Mountain ranges & 59.12 & 269 & Motorways & 8.79 & 40 \\
\hline Clouds & 51.65 & 235 & Cars & 6.37 & 29 \\
\hline Country roads & 44.84 & 204 & Other & 5.05 & 23 \\
\hline Showers & 41.1 & 187 & I don't know & 0.22 & 1 \\
\hline Single flowers & 35.38 & 161 & & & \\
\hline
\end{tabular}


Due to their cultural, societal conditioning, the cognitive as well as the aesthetic and emotional ratings exhibit great stability in regard to specific perception, interpretation, evaluation and behaviour patterns, but are nonetheless subject to steady permutation in the wake of societal and individual change (Hartz \& Kühne 2009). So, from a constructivist point of view, landscape cannot be scaled in an objectively correct way, but is a product of a combination of subjective, socially preconditioned perceptions of our surroundings and is subject to assigned meanings. This has far-reaching consequences for landscape architecture, planning and practice.

As well as landscape (and in the tradition of the philosophy of nominalism, all complex ideas; see Goodman 1968), nature and culture can be described as social constructs and individual constructs based on socialised social beliefs. The social representation of what we call nature is the result of a long chain of translations. The use of this transformation is a yield of compatibility, standardisation, text, account, circulation, and relative universality (Latour 1999): all of us seem to know what it means when we hear the word 'nature'.

\section{Forms of nature in cities}

The evolution of human society can be understood as a process of emancipation from interior and exterior 'nature' (Horkheimer 1982). In the civilising process (Elias 2000), 'natural' components of human beings, such as emotions, are pushed into the background in favour of 'cultural' components, such as cognitive capacity and artificial behaviour. Humans can not only be conceptualised as 'cultural' beings but are hybrids: the body shows a tendency to the 'natural' dimension domesticated by 'cultural' components, such as haircuts, whereas the spirit tends to the 'cultural' dimension (Latour 1999). Society's perception of what we call nature is still ambivalent: nature describes "the primary and the good (...) that contrasts with society as the artificial and even the destructive". Nevertheless nature means "the wild and the threatening, which is domesticated to protect the society" (Groß 2006: 5). This ambivalent construction is based on the mod- ernisation of society: economic evolution seems to have alienated man from his biological basis and ruined his links with nature. The findings of the natural sciences and an apparently growing, technical mastery of nature formed the prerequisites for an aesthetisation of spatial objects and symbols into landscape (Kühne 2006). The aesthetisation of nature and landscape emerged from the alienation of what we call nature on the one hand and the availability of aesthetic education on the other: the 'enlightened' individual of the $18^{\text {th }}$ and $19^{\text {th }}$ centuries who was "reading idealised concepts of a relationship between society and culture" (Jessel 2004: 22) into rustically fashioned rural landscapes was neither an impoverished farmer nor a labourer in the newly created industries, but an urban middle-class citizen (see Hartz \& Kühne 2009). In cities, nature takes either the most domesticated shapes, such as lifeless natural elements like minerals or ornamental plants which represent nature in inner cities or shopping malls, or more domesticated shapes, such as plants in gardens or parks, or appears in a less domesticated shape, such as sparse vegetation. In every condition the urban landscape is only built of hybrids of untouched nature, such as minerals and cultural elements (see Fig. 1). The less domesticated shapes appear as 'no man's land' which can be described as an "open space between the corpus of the city and its too large tailored suit of planning" (Burckhardt 1980: 140).

In urbanised societies, people are mainly confronted with nature in an urban context. The dominant kind of natural areas in this context is parks. Many of those parks are inspired by the paradigm of landscape gardening. These landscape gardens are a physical manifestation of idealised landscapes based on landscape painting in the early modern times (Clifford 1962). In

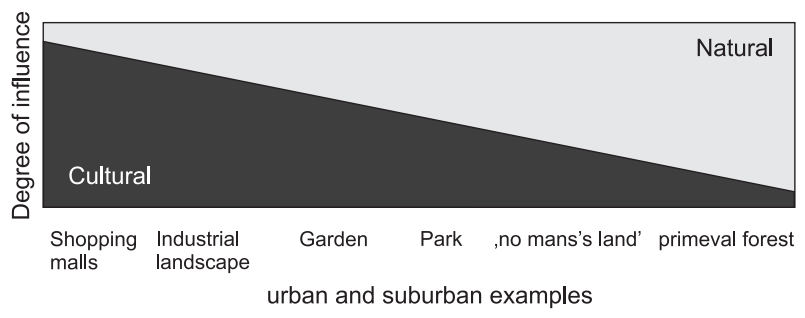

Fig. 1. Different degrees of hybridity of various urban landscapes. Source: Kühne (2006). 
the course of socialisation (in the urban-context landscape), gardens took on a dominant role in moulding social beliefs concerning nature and landscape. Landscape gardens "provide the usual ideal of beauty, of a harmonious and natural landscape, even (if) a landscape garden is intensively formed by human beings and its maintenance is very labour intensive" (Jessel 2005: 580).

The longing for living in a 'natural' landscape in the sense of a landscape garden was both a supporter of suburbanisation and caused by it. Nevertheless, the recent hybrid of culture and nature, viz. suburban landscapes, has developed by the superimposition of continuing suburbanisation on postmodern urbanisation processes. Economic change leads to a reform of the (sub)urban landscape, especially in combination with the de-industrialisation of large parts of Western and Central Europe and North America, and the diversification of lifestyles and milieus. "In particular, the fragmentation of metropolitan structures into independent settlement areas, urban economies, societies and cultures is being identified as an eminent attribute of postmodern urbanisation (heteropolis)" (Wood 2003: 133; see also Hartz \& Kühne 2009). The development of postmodern heteropolis implies the pluralisation of different influences of culture and nature in different places (see Dear 2000, Soja 2000). So, a patchwork of different places and spaces with different degrees of natural and cultural influence is formed in the postmodern heteropolis.

\section{Modern and postmodern aesthetics}

The division of modernity and postmodernity (as an ideal type of configuration concerning structures and functions; see Vester 1993) has been discussed in the social sciences for more than 30 years. Besides an economic and a social dimension, such as globalisation, pluralisation and individualisation, postmodernity has a constitutive aesthetic dimension. It is assumed that the antagonism of legitimised and trivial culture is a substantial characteristic of modernity. This modern thinking is incorporated in a series of fundamental dichotomies, like male and female, nature and culture, or city and landscape (Fuller 1992). The relationship between modernism and postmod- ernism (as theoretical concepts; see Vester 1993) is not characterised by a clear distinction: "Postmodernism is not so much a critique or radical refusal of modernism but its radical exaggeration. It is more modern than modernism. Postmodernism hyperbolically accentuates the processes of increased turnover time, speed of circulation and the disposability of subjects and objects" (Lash \& Urry 1994: 3). A central idea of postmodernism is incredulity towards meta-narratives (Lyotard 1979). Meta-narratives, i.e. the narrative of the Enlightenment, of Marxism, of Christendom, and of Capitalism, Lyotard (1979) claims, are grand theories and philosophies of the world, characterised by their ideology of exclusiveness. They feature a concurrence of authority. The postmodern cancellation of these meta-narratives as teleological dreams of salvation means a turn to small narratives with a limited claim of validity: „We cannot have laws which hold everywhere and always, but we can construct knowledge specific to particular contexts in time and space" (Byrne 2001: 33). Postmodern thinking means inclusivist instead of exclusivist thinking (Sloterdijk 1987), which is caused by the values of freedom, difference and tolerance (Bauman 1992). Postmodernity reinstalls emotions as a frame of reference by overcoming the faculty of reason as the only accepted framework.

With this rehabilitation of emotions, the aesthetic mode of the sublime gains in importance in comparison with the aesthetic mode of beauty (Jameson 1984, Lyotard 1979). The postmodernism aestheticises in cases where previously only a purely enlightened and strictly rationally-oriented model applied (in the modern period). In the postmodern era, reality is increasingly revealed to be not 'realistically' but 'aesthetically' constructed (Welsch 1995). The perception of space is, according to Jameson (1984), intensified. Landscape is no longer merely a secondary consequence of a particular economic activity, but variously encoded: landscape is assigned the tasks of educating, admonishing, delighting, and astounding. It deals with a state of landscape that has in many ways lost its economic function. Encoding landscape provides it with a symbolic charge. This symbolic loading of landscapes - in this case, of townscapes in particular - is, in postmodernism, often linked to a valorisation of arte- 
facts from the past. This reinterpretation is based on an appreciation not only of the historic and the pre-modern age, but partly also the modern age (Kühne 2008, Hartz \& Kühne 2009). As a consequence of postmodernism, the organisation of space changes (Harvey 1989: 304): „Whereas modernism looked upon the spaces of the city, for example, as an epiphenomenon of social functions, postmodernism tends to disengage urban space from its dependence on functions and to see it as an autonomous formal system incorporating rhetorical and artistic strategies which are independent of any simple historical determinism".

In the postmodern era, the media play a decisive role in the process of the recycling and recombination of spaces, landscapes, townscapes and nature. "The postmodern machine, organized by the logic of simulacrum, reproduces, rather than produces. The aesthetic embodiment of this process, especially in advertising, film, and television, does more than merely replicate the logic of late capitalism; it reinforces and intensifies it" (Jameson 1984: 85). This virtual production causes a decreasing relevance of physical objects for the construction of the world, like landscape, nature, culture; a process that itself reinforces the relevance of virtual construction (Baudrillard 1994).

\section{An appraisal of urban nature}

From the aesthetic point of view, modernity and postmodernity have different implications in the perception and assessment of urban nature. Especially less domesticated nature contradicts the modern aesthetic scheme. A typical modern dichotomy is the construction of order and disorder. One of the essential aims of modernity is 'Reinheit', which means a synthesis of purity, cleanness and spruceness in German. The modern quest for 'Reinheit' takes place in an exclusivistic way. From the modern point of view, lack of 'Reinheit' is to be classified as a problematic status, caused by a departure from this social norm. This departure is to be eliminated by implementing 'Reinheit' (Fayet 2003). In the urban context, the modern quest for 'Reinheit' implies that all kinds of deviance, especially deviation towards dirt, is to be eliminated. Besides inorganic ob- jects, the label of 'dirt' also embraces live objects. The elimination of dirt is a permanent process because - to keep up its physical functions - the human body is "a dirt-producing existence" (Hasse 2000: 38). The visual elimination of dirt from the townscape symbolises "in an anthropological perspective a concrete form of building a distance between human life and its natural as well as physical and material condition of existence" (Hasse 2000: 38). In this context, "the neat city (cleaned from dirt)" produces a distance not only towards "one's own human nature, but also towards the exterior nature" (Hasse 2000: 39). The modern clean city symbolises the idea of superiority of modern culture to nature, and of reason as an element of culture to emotion as an element of nature. On the other hand, the clean and neat (in the sense of aesthetics: beauty) symbolises modern well-organised relationships: the city as an expression of culture shall not be polluted by non-organised nature. Non-organised nature is banished from the city. In the modern city, nature is admitted in a well-ordered (in the sense of controlled) form, as in gardens and parks. Another form of acceptance of nature in the city is its periodic 'adornment' with Christmas trees, the narrowness of which is not only terminated by the calendar, but also by the dropping of needles (another symbol of the superiority of culture to nature).

From the perspective of modernity, 'no man's land' is perceived as disorder and is therefore rejected. It is a symbol of the possibility of resistance of nature to modern culture and its ambitions to implement 'Reinheit'. From the aesthetic point of view, the resistance of 'no man's land' with its sparse vegetation to a well-ordered status of the urban landscape refers to the mode of the sublime. Sparse vegetation transcends the scary power of nature. 'No man's land' with its sparse vegetation also represents the existence of a hybrid in the city: the modern stereotype of the city as a product of culture allows neither nondomesticated natural elements in it, nor ambiguity, seen as the hybrid's dissent to the modern quest for constructing the world in dichotomies like nature and culture. Concerning the interior and exterior nature, especially in its hybrid forms, the modern city pursues strategies of fadeout and domestication. These strategies alienate 
modern human beings from their natural roots, with fatal consequences: the modern strategy of fading waste out as an "ideological project to fabricate an illusion of beauty" (Hasse 2000: 37) causes damage to ecosystems which - because of its invisibility - is not easy to observe by lay persons or politicians.

By contrast to modern aesthetics, postmodern aesthetics challenges and deconstructs the dichotomies of city and landscape, culture and nature, cognition and emotion (Sloterdijk 1987, 1988). The theory of postmodernity accepts hybridity. Unlike modernity, postmodernity tolerates the less domesticated nature in cities. This tolerance opens up new possibilities of the composition of the cityscape, especially for ruined buildings and areas. Not only well-tended parks are assessed as desirable, but also untidy areas with sparse vegetation; such spaces are socially labelled as interesting. In opposition to modernity, postmodernity has found an aesthetic mode to get involved with things which were wasted in modern times. Postmodernity "uses the richness of historic waste and practices as continuous recycling of stocks from the sphere of discarded to the sphere of the accepted" (Fayet 2003: 167). This new world outlook manifests physical space by maintaining objects of the modern and premodern eras: historic pits and industrial facilities are no longer demolished, but restored, re-used, or they decay in dignity. The affinity of the postmodern world outlook to the sublime helps it to accept non-ordered nature in cities: non-ordered vegetation in the city does not challenge the superiority of culture any longer, as it did in the modern era. On the one hand, in principle it represents openness towards a new life experience; on the other, it symbolises the transcendence of nature. Thus, it reflects the natural foundation of human existence.

\section{Practical planning and practical experiences}

The increasing complexity of societies and their demands on spaces, places and landscapes, especially in agglomerations, overload traditional formal planning systems. Any form of spatial planning that wishes to accommodate societal developments cannot go on being organised by means of hierarchically exclusive planning concepts. Social conditions have changed, and a number of factors, such as the erosion of national and sub-national political power, the diversity of strong regional players, the intensity of spatial interconnections over and beyond administrative boundaries, and the complexity of decision-making processes, now greatly restrict the possibility of implementing top-down planning (see Beck 1992). In addition, an expert status of the volonté général becomes questionable in a society characterised by individualisation, social fragmentation and a fundamental transformation of values (Hartz \& Kühne 2007, 2009). From the social constructivist point of view, planning authorities follow the needs and perceptions of citizens when constructing new landscapes. However, owing to their professional bias, experts have a different construction of landscape than lay persons (Bourassa 1991). Planning - against the background provided by the wide range of approaches described - rather has to perform landscaping in cooperation with its inhabitants and users, and in accordance with their requirements (Hartz \& Kühne 2010).

The constructivist perspective also implies a shift in planning objectives. While the positivistic type of planning measures its success in the perfection of target achievement, the quality of symbolic-realistic planning is rated by the degree of integration of those affected by the planning process and the result (Brown 1989, Hartz $\&$ Kühne 2009). The constructivist perspective in combination with a postmodern approach leads to an ironic dealing with place, space and landscape. This ironic-reflexive handling of handeddown interpretation patterns stimulates a change of perspective by seeing urban landscapes in a new way and discovering their potential. In this way, objects otherwise rejected as banal and inexpressive are aesthetically loaded and rendered available for a new experience (Hartz \& Kühne 2009). The integration of a lay person into the planning process as well as the focus on a social construction of (urban) landscapes needs the development or adaptation of methods of social and cultural sciences and leads to an integration of the social dimension of sustainable development into planning. The polyvalent patchwork in 


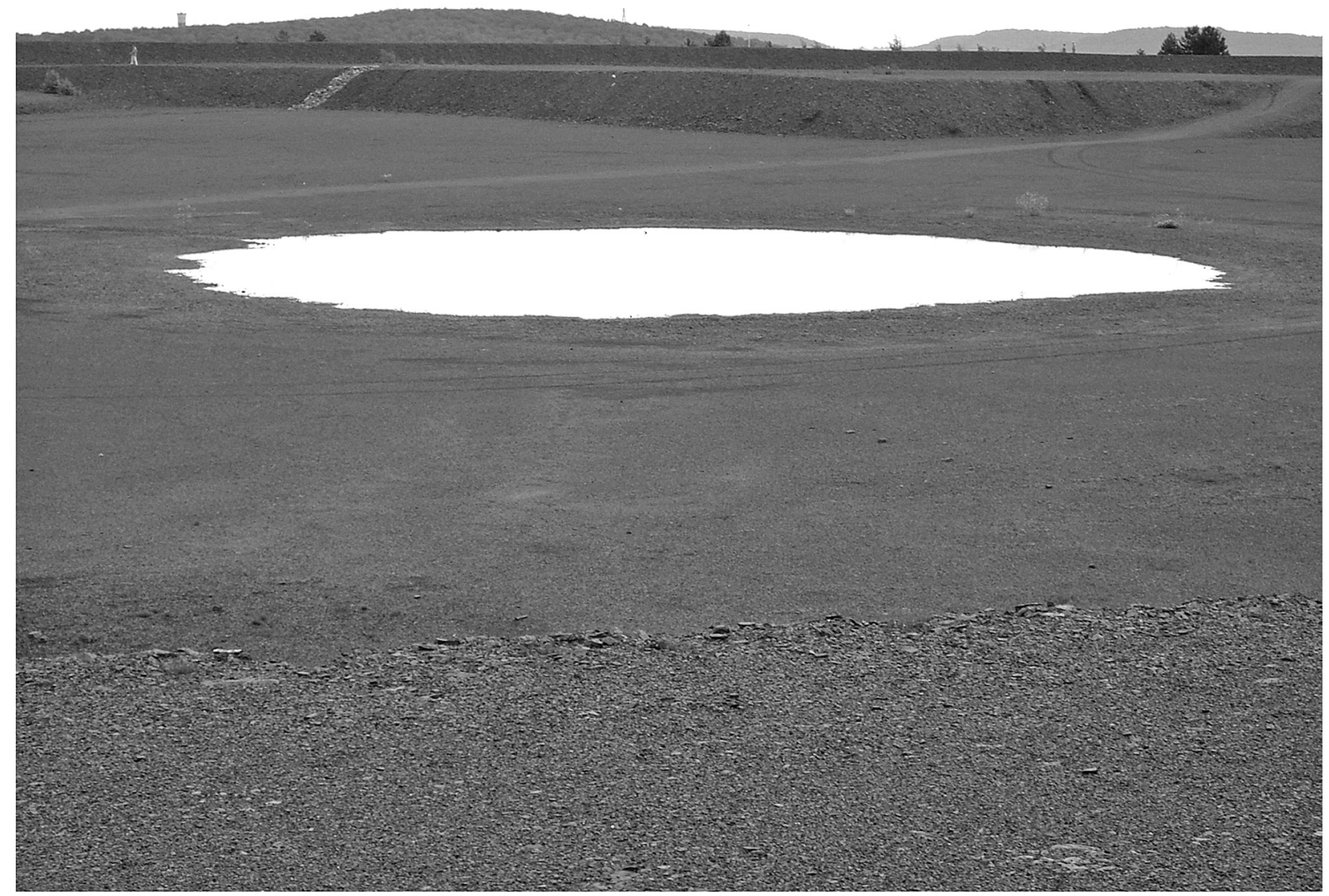

Fig. 2. An example of the concept of the acupuncture of landscape: The 'Himmelsspiegel' (Mirror to the sky) on the 'Lydia' dump near Saarbrücken (Germany), a pond with a changing water level. Photo by O. Kühne.

urban landscapes which represents the requirements of inhabitants and users can be described as an expression of the postmodern aesthetics of tolerance. The postmodern ambiguous (urban) landscape can be understood as a symbol of a democratic variegated society. In this context the renouncement of unambiguousness gives the possibility of a re-enchantment and mystification of (urban) landscapes. This also means a conscious return to models of a romantic interpretation of landscape (Kühne \& Franke 2010). A postmodern recollection of the romantic as "the dark backside of the Enlightenment" (Illing 2006: 48) also means an increase in the significance of (urban) nature as an ecological dimension of sustainability. This increasing importance of (urban) nature may cause a stronger phenomenological admission to nature. If the process of socialisation refers to physical objects rather than to virtual realities, the postmodern appreciation of na- ture will not end in a passive theory, but could become an integral part of sustainable development.

The presented concept is implemented in three practical projects in Saarland, a state lying in the south-western part of Germany: the development of the Biosphere Reserve 'Bliesgau' (Kühne 2010), the New Urban Landscapes project - SAUL (Sustainable and Accessible Urban Landscapes; Hartz \& Kühne 2007, 2009), and the Large-Scale Nature Conservation Project of the Landscape of Industrial Culture North (Hartz \& Kühne 2010). One of these projects, the New Urban Landscapes SAUL, will now be described in more detail.

The New Urban Landscapes - SAUL project, with its key issues of future-oriented development strategies for urban landscapes, accessibility and social inclusion, planning in partnership, and the concept of learning regions, was co-funded under the EU initiatives Interreg IIC and Inter- 
reg IIIB. It is based on six key components (Hartz \& Kühne 2009):

- Learning to 'read' urban landscapes - changing patterns of perception, with the main topics of reflection on and qualification (and possibly modification) of our perception of urban nature.

- Changing contexts and meanings - re-encoding spaces. A special role in landscapes is played by symbols and the attribution of meanings. These symbols and attributions can be changed in the process of social development.

- Improving accessibility: networking spaces opening up to new uses. Residual spaces in urban landscapes can be opened up for active use by the application of intelligent, often simple concepts.

- Point-by-point intervention - acupuncture of urban landscapes. The re-invention of urban landscapes does not need to have a large-scale dimension. Acupuncture of landscapes means changing small aspects with a small financial impact to create a change in perspective concerning the social construction of landscapes (see Fig. 2).

- Temporary places through temporary interventions. Landscape design should not be planned for eternity: future generations must have an opportunity to create physical objects easily satisfying their needs without heavy decommissioning and reinstating costs.

- Aesthetic reflection in the planning process. Citizens, artists, planners and project-responsible bodies should be linked together in a network through the project, and the planning process itself should be designed as an in situ experience.

These projects are inspired by the needs of a postmodern society and the demand for sustainability. They try to re-integrate nature into social construction as an important dimension of life. The patchwork of cultural and natural hybrids gives people the possibility to read, experience and re-invent landscape in a different way. The presented projects offer the users and inhabitants the possibility of constructing landscape individually on the basis of phenomenological impressions (but social knowledge, stereotypes and patterns as well). This way of designing and planning landscapes includes doing without a 'great plan' - in a sense of a meta-narrative, which goes along with an exclusivistic logic. This way is based on the postmodern mode of the concept of 'small narratives'.

\section{Conclusion}

Postmodern theory includes aesthetic, analytical and normative components of what we call nature and how we deal with it. Goodman (1992) allows art and science to be viewed as not clearly separable but rather mutually interdependent types of world-fashioning. In consequence, aesthetics can be understood as a special form of epistemology. The proximity of aesthetics and science also becomes clear when Goodman (1968: 242-243) characterises the aesthetic as a scientific attitude to "the restless, inquisitive, scrutinizing". The hegemonic claims of universal interpretation patterns in the sense of meta-narratives are untenable from a social constructivist perspective. From this perspective, the search for universal aesthetic regularities would have to be described as some kind of "an astrology of aesthetics" (Croce 1930: 117). The same should apply to any search for the general laws of beauty, which would then be described as meta-narratives (see also Hartz \& Kühne 2010). This induces a perspective of tolerance, variety and pluralism concerning the different interpretations and ascriptions to place, space and landscape. Hegemonies in landscape interpretations and in norms of designs contradict this landscape philosophy. The transition of postmodernity from exclusivist to inclusivist thinking releases the onlooker from pre-fabricated space interpretations. It provides individual access to a comprehension of local narratives that takes place at both, a cognitive and an emotionalaesthetic level (Hartz \& Kühne 2007). Postmodern landscape planning and architecture does not mean 'anything goes', but rather an inclusion of the pluralism of citizens' interests, belongings and needs, especially because they are the sovereigns in democratic societies. Equal opportunities as a basis of social sustainability are implemented in the planning process more intensively than in the top-down planning system. Furthermore, the acceptance of sparse vegetation instead of sealed 
surfaces means an improvement of the ecological status of cities in terms of better air quality and greater urban biodiversity - a significant contribution towards an ecologically sustainable development.

\section{References}

BAUDRILlARD J., 1994 (1 $1^{\text {st }}$ ed. 1979). Simulacra and simulation. University of Michigan Press, Ann Arbor.

BAUMAN Z., 1992. Intimations of postmodernity. Routledge, London.

BECK U., 1992. Risk society. Towards a new modernity. Sage, London.

BOURASSA S.C., 1991. The aesthetic of landscape. Belhaven Press, London.

Brown R.H., 1989. Social science as a civic discourse. Essays on the invention, legitimation and uses of social theory. University of Chicago Press, Chicago.

BuRCKHARDT L., 1980. Niemandsland (No man's land). In: Burckhardt L. (ed.), Warum ist Landschaft schön? Die Spaziergangswissenschaft. Schitz, Kassel: 140-141.

BYRne D., 2001. Understanding the urban. Palgrave Macmillan, Houndmills, New York.

CLIFFord D., 1962. A history of garden design. Faber and Faber, London.

Croce B., 1995. Guide to aesthetics. Hackett Publ., Cambridge, Indianapolis.

Davis M., 1998. Ecology of fear. Los Angeles and the imagination of disaster. Metropolitan Books, New York.

DeAR M.J., 2000. The postmodern urban condition. Blackwell, Oxford.

Elias N., 2000 (1 $1^{\text {st }}$ ed. 1939). The civilizing process. Sociogenetic and psychogenetic investigations. Blackwell, Oxford.

FAyET R., 2003. Reinigungen. Vom Abfall der Moderne zum Kompost der Nachmoderne (Purifications. From the waste of the modern to the compost of the postmodern). PassagenVerl., Wien.

FLusty S., 1997. Building paranoia. In: Ellin N. (ed.), Architecture of fear. Princeton Architectural Press, New York: 48-52.

Foerster H. v., 1992. Entdecken oder Erfinden. Wie lässt sich Verstehen verstehen? (Discover or invent. How is understanding to be understood?). In: Gumin H. \& Meier H. (eds), Einführung in den Konstruktivismus. Piper, München, Zürich: 41-88.

Fuller G., 1992. Kitsch-Art. Wie Kitsch zur Kunst wird (Kitschart. How kitsch gets to be art). DuMont, Köln.

GoODMAN N., 1968. Languages of art: an approach to a theory of symbols. Bobbs-Merrill, Indianapolis.

Goodman N., 1992. Kunst und Erkenntnis (Art and knowledge). In: Henrich D. \& Iser W. (eds), Theorien der Kunst. Suhrkamp, Frankfurt a. M.: 569-591.

Gross M., 2006. Natur (Nature). Transcript, Bielefeld.

Hartz A. \& KÜHNE O., 2007. Der Regionalpark Saar - eine Betrachtung aus postmoderner Perspektive (The Regional Park Saar - an investigation from the perspective of postmodernity). Raumforschung und Raumordnung, 1: 30-43.

Hartz A. \& KüHne O., 2009. Aesthetic approaches to active urban landscape planning: European exemplars. In: van der Valk A. \& van Dijk T. (eds), Regional planning for open space. Routledge, London: 249-278.
Hartz A. \& KüHnE O., 2010. Large-scale nature conservation projects as impulse for a pro-active landscape policy in postindustrial regions. In: Carsjens G.J. (ed.), Landscape legacy: Landscape architecture and planning between art and science. Proceedings of CELA-ISOMUL conference, May 12-14, 2010. Maastricht.

Hasse J., 2000. Die Wunden der Stadt. Für eine neue Ästhetik unserer Städte (The wounds of our city. Towards a new aesthetic of our cities). Passagen-Verl., Wien.

Harvey D., 1989. The condition of postmodernity. Blackwell, Oxford.

HorkHeImer M., 1982 (1 $1^{\text {st }}$ ed. 1937). Critical theory: selected essays. Continuum Pub. Corp., New York.

ILLing F., 2006. Kitsch, Kommerz und Kult. Soziologie des schlechten Geschmacks (Kitsch, commerce and cult. Sociology of bad taste). UVK-Verl.-Ges, Konstanz.

JAMESON F., 1984. Postmodernism, or the cultural logic of late capitalism. New Left Review, 146: 53-92.

Jessel B., 2004. Von der Kulturlandschaft zur LandschaftsKultur in Europa. Für die Zukunft: Handlungsmaximen statt fester Leitbilder (From cultural landscape to landscape culture in Europe. For the future: guiding principles instead of fixed mission statements). Stadt + Grün, 2: 20-27.

Jessel B., 2005. Landschaft (Landscape). In: Ritter E.-H. (ed.), Handwörterbuch der Raumordnung. Verlag der ARL, Hannover: 579-586.

KüHne O., 2006. Landschaft in der Postmoderne. Das Beispiel des Saarlandes (Landscape in the postmodern era. The example of the German state Saarland). Deutscher Universitäts-Verlag, Wiesbaden.

KüHNE O., 2008. Distinktion - Macht - Landschaft. Zur sozialen Definition von Landschaft (Distinction - power - landscape. Towards the social definition of landscape). VS, Wiesbaden.

KÜHNE O. \& FRANKE U., 2010. Romantische Landschaft. Impulse zur Wiederentdeckung der Romantik in der Landschafts- und Siedlungsgestaltung in der norddeutschen Kulturlandschaft. Ein Plädoyer (Romantic landscape. Impulses to the rediscovery of romantic in the design of landscapes and settlements in the north German cultural landscape. A plea). Oceano, Schwerin.

LASH S. \& URrY J., 1994. Economies of signs and space. Sage, London.

Latour B., 1999. Pandora's hope: essays on the reality of science studies. Harvard University Press, Cambridge, London.

LyOtARD J.-F., 1979. La condition postmoderne: rapport sur le savoir (The postmodern condition: a report on knowledge). Les Éditions de Minuit, Paris.

Maturana H. \& Varela F., 1987. The tree of knowledge: the biological roots of human understanding. Shambhala, Boston.

Planungsgruppe agl, 2008. Projektantrag Landschaft der Industriekultur Nord (Saarland) (Project proposal of industrial culture landscape North (Saarland)). Ministerium für Umwelt, Saarbrücken.

Schütz A., 1971. Gesammelte Aufsätze 1. Das Problem der Wirklichkeit (Collected essays. The problem of reality). Nijhoff, Den Haag.

SсHÜтz A., 1972. The phenomenology of the social world. Northwestern University Press, Evanston.

Simmel G., 1990 (1 $1^{\text {st }}$ ed. 1913). Philosophie der Landschaft (Philosophy of landscape). In: Gröning G. \& Herlyn U. (eds), Landschaftswahrnehmung und Landschaftserfahrung. Minerva-Publ, München: 67-80. 
SLOTERDIJK P., 1987. Kopernikanische Mobilmachung und ptolemäische Abrüstung. Ästhetischer Versuch (Copernican mobilisation and Ptolemaic disarmament. An aesthetic try). Suhrkamp, Frankfurt am Main.

SLOTERDIJK P., 1988. Critique of cynical reason. University of Minneapolis Press, Minneapolis.

Soja E.W., 2000. Postmetropolis. Critical studies of cities and regions. Blackwell, Oxford.

Solso R.L., MacLin O.H. \& MacLin K., 2008. Cognitive psychology. Pearson, Allyn and Bacon, Boston, Munich.

UNESCO, 2009. International Coordinating Council of the Man and the Biosphere (MAB) Programme. Twenty-first session, 25-29 May 2009, http://www.unesco.org/mab/doc/ icc/2009/e_NewBRs.pdf.
Vester H.-G., 1993. Soziologie der Postmoderne (Postmodern sociology). Quintessenz, München.

Welsch W., 1995. Ästhetisches Denken (Aesthetic thinking). Reclam, Stuttgart.

Wood G., 2003. Die postmoderne Stadt: Neue Formen der Urbanität im Übergang vom zweiten ins dritte Jahrtausend (The postmodern city: New forms of urbanity in the transition from the second to the third millennium). In: Gebhardt H., Reuber P. \& Wolkersdorfer G. (eds), Kulturgeographie - Aktuelle Ansätze und Entwicklungen. Spektrum, Heidelberg, Berlin: 131-147. 